\title{
Scoping Review of Mental Health Problems among Female Prisoners
}

\author{
Nur Oktavia Hidayati ${ }^{1,2 *(\mathbb{D})}$, Suryani Suryani ${ }^{1} \mathbb{D}$, Laili Rahayuwati $^{3} \mathbb{D}$, Nur Setiawati Dewi $^{4} \mathbb{D}$ \\ ${ }^{1}$ Department of Mental Health Nursing, Faculty of Nursing, Universitas Padjajaran, Bandung, Indonesia; ${ }^{2}$ Doctoral Study \\ Program, Faculty of Medicine, Universitas Padjadjaran, Bandung, Indonesia; ${ }^{3}$ Department of Community Nursing, Faculty of \\ Nursing, Universitas Padjadjaran, Bandung, Indonesia; ${ }^{4}$ Department of Nursing, Faculty of Medicine, Universitas Diponegoro, \\ Semarang, Indonesia
}

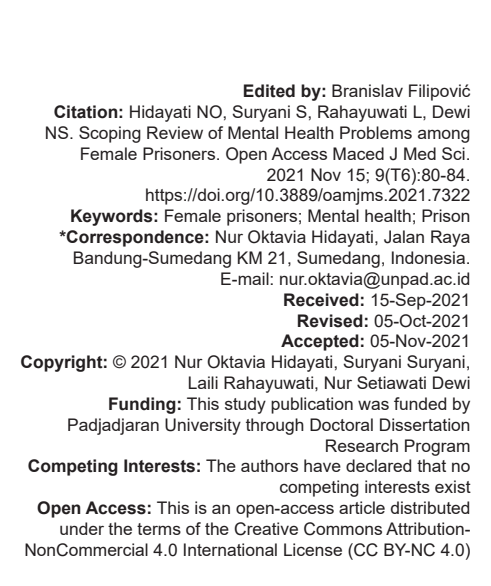

\section{Abstract}

BACKGROUND: Detention can cause problems and stressors for prisoners, one of which is mental health problems Female prisoners have a high rate of mental health needs in prisons. Awareness and the ability to recognize prisoners' health problems are important. Therefore, the mental welfare of female prisoners is the responsibility of each prison.

AIM: This review aimed to identify mental health problems among female prisoners.

METHODS: The method used was a scoping review. A systematic searched of the literature between 2000 and August 2021 on several databases and search engines, namely, PubMed, CINAHL, SAGE Journals, and Google Scholar using keywords in English, namely, mental health, female prisoners, and prison.

RESULTS: Of the 112 articles found, nine were eligible for inclusion. It was found that the mental health problems of female prisoners were anxiety, depression, substance abuse, stress, loss and grief, trauma, and suicide attempts that put them at risk of psychological distress. There was still limited study on female prisoners, especially to explore mental health problems in prison, and there were few studies discussing adjustment to female prisoners in prison, as well as mental health services which are still rarely carried out in prisons.

CONCLUSION: Based on the findings, it is recommended for future research to focus more on how female prisoners can access mental health services in prisons to overcome their mental health problems, conduct a deeper exploration of the extent to which mental health services in prisons have been carried out so far.

\section{Introduction}

More than 10 million people worldwide are imprisoned and the prevalence of mental disorders in prisoners is higher than in the general population. Although mental disorders are often experienced by prisoners, these disorders are often undiagnosed and not treated properly [1]. Some of the mental health problems that many prisoners experience are depression, life dissatisfaction, consuming alcohol, and using narcotics. These problems are related to the poor facilities of public health workers [2]. The experience of detention for inmates is a challenge for mental health nurses. Untreated mental health conditions lead to poor adjustment to life in prison. In addition, prison conditions are also a challenge for inmates who have mental health conditions [3].

Research that has been conducted shows that the demographic characteristics, health, and forms of crime in female prisoners is different from those of men [1]. Bureau of Justice Statistics Special Report in the edition of the Diagnostic and Statistical Manual of Mental Disorders states that female prisoners have higher mental health problems than male prisoners [4].
Studies show that mental health-care facilities in prisons are rarely available. The mental welfare of prisoners is the responsibility of each prison; therefore, awareness and ability to recognize prisoners' health problems are very important [5].

Women are a vulnerable group, both physically and psychologically. Likewise, female prisoners are vulnerable to mental health problems. Some of the most common mental health problems among female prisoners are psychological distress and depression. Mental health symptoms in female prisoners need to be checked from time to time, this can be done together with appropriate medication and treatment to prevent chronic mental illness. Chronic mental illness and poor psychological health lead to destructive behavior while in prison [6].

Female prisoners have a high level of mental health needs in prison, thus further research is needed on what mental health problems and the factors that influence them are, especially to prevent more serious mental disorders [6]. Meanwhile, research or review on mental health problems in female prisoners is still minimal and difficult to find. Therefore, the authors conducted a scoping review to identify mental health problems in female prisoners. 


\section{Methods}

We conducted a scoping review using the methodology described by Arksey and O'Malley [7] which consists of five stages: (1) Identifying the research question, (2) identifying relevant studies, (3) study selection, (4) charting the data, and (5) collecting, summarizing, and analyzing the included literature. This review decision process was presented in a PRISMA flow diagram.

\section{Identifying the research question}

The research question in this study was "what are the mental health problems in female prisoners?"

\section{Identifying relevant studies}

We conducted a systematic literature search in several databases and search engines: CINAHL, PubMed, SAGE Journals, and Google Scholar between 2000 and August 2021. This study used keywords in English: Mental health OR mental health problems OR mental illness OR mental disorder AND female prisoners OR female inmates OR incarcerated women AND prison OR jail.

\section{Study selection}

We selected articles by reading abstracts and titles and then sorted them by inclusion criteria: Articles describing mental health problems among female prisoners, any countries, and full texts.

\section{Charting, collecting, summarizing, and analyzing the data}

Three authors (NOH, NSD, and LR) mapped the data and created an extraction (Table 1), consisting of authors, year of publication, research location, objective, sample size, study design, and assessment tools. Two authors (SY and $\mathrm{NOH}$ ) reviewed and refined the results of the analysis that had been made.

\section{Results}

\section{Study selection}

Based on searches of databases and search engines found 405 articles, after removal of duplicate and initial screening, we reviewed 112 articles. After reviewing these articles against the exclusion criteria, nine papers were included in the study.

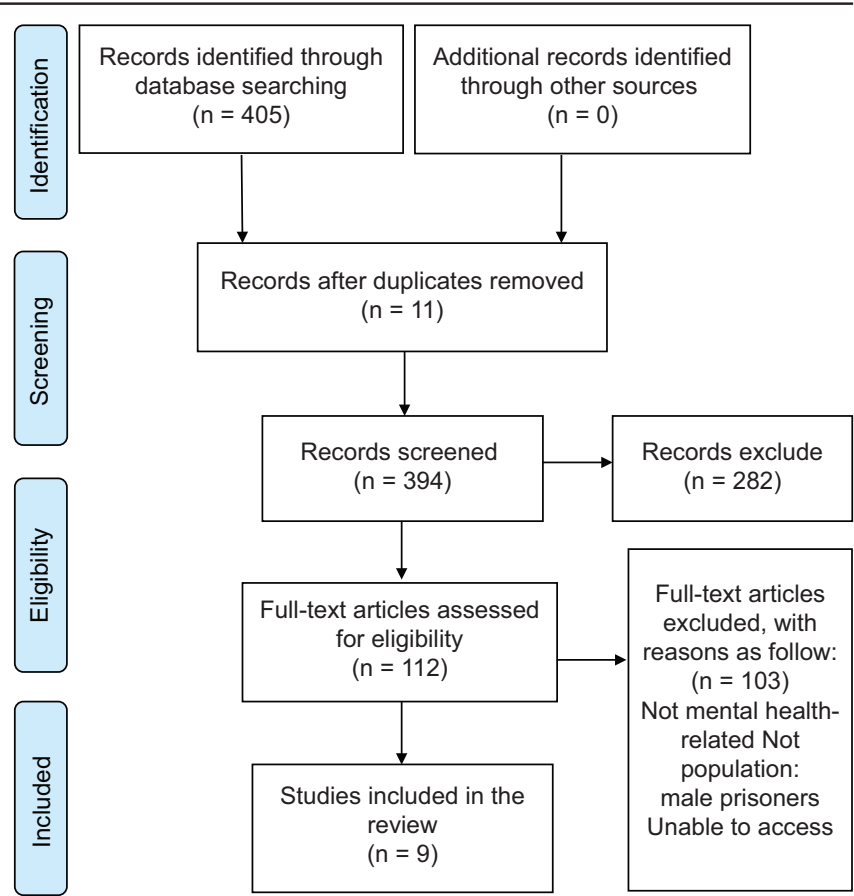

\section{Study characteristic}

Most of the articles were quantitative studies, two cross-sectional studies, three correlation studies, one mix-method study, one critical study, one survey study, one clinical interview study, and one qualitative study. Research was conducted in various countries, such as the USA (4), Spain (2), and one article from the UK, Poland, and Indonesia year of publication of the nine articles between 2011 and 2021. Most studies use assessment tools (eight articles), such as Depression Anxiety Stress Scale-21, Millon Clinical Multiaxial Inventory Third Edition, Severity of Dependence Scale, Alcohol Use Disorders Identification Test (AUDIT-PC), Suicide Behavior Questionnaire-Revised, SCOFF, Prison Health Survey, Clinician-Administrated PTSD Scale, Structured Clinical Interview for DSM-IV Non-patient Version, Trauma History Questionnaire and The Life Stressor Checklist-Revised, The Resilience Measurement Scale-RMS-25, Hospital Anxiety and Depression Scale, Medical Outcomes Study Social Support Survey, AUDIT-C, Life stressor Check list Revised, and Global Appraisal of Individual Needs, Spielberger's The State Anxiety Inventory and one article was a qualitative study.

\section{Mental health problems}

From the results of research that has been carried out (Table 2), several mental health problems were found. In the study of Tyler et al. [8], as many as $34.4 \%$ of female prisoners experienced anxiety, $32.8 \%$ experienced depression, and $22.9 \%$ had PTSD. Substance abuse and alcohol misuse are the highest compared to other mental health problems. 
Table 1: Data extraction

\begin{tabular}{|c|c|c|c|c|}
\hline Authors, year, country & Objectives & Sample size & Study design & Assessment tools \\
\hline $\begin{array}{l}\text { Tyler et al., (2019) } \\
\text { UK [8] }\end{array}$ & $\begin{array}{l}\text { To measure the prevalence and comorbidity of } \\
\text { mental health needs }\end{array}$ & 131 female prisoners & Cross-sectional study & $\begin{array}{l}\text { Millon Clinical Multiaxial Inventory Third Edition } \\
\text { (MCMI-III), Severity of Dependence Scale } \\
\text { (SDS), Alcohol Use Disorders Identification Test } \\
\text { (AUDIT-PC), Suicide Behavior Questionnaire- } \\
\text { Revised (SBQR), and SCOFF }\end{array}$ \\
\hline $\begin{array}{l}\text { Harner and Riley (2013) } \\
\text { USA [9] }\end{array}$ & $\begin{array}{l}\text { To examines, women's perceptions of how } \\
\text { incarcerated had affected their mental health }\end{array}$ & $\begin{array}{l}900 \text { incarcerated women in } \\
\text { Stage One } 65 \text { incarcerated } \\
\text { women in Stage Two }\end{array}$ & $\begin{array}{l}\text { Descriptive surveys and } \\
\text { focus groups }\end{array}$ & Prison Health Survey (PHS) \\
\hline $\begin{array}{l}\text { Sanchez et al. (2019) } \\
\text { Spain [10] }\end{array}$ & $\begin{array}{l}\text { To examines, the prevalence and magnitude of } \\
\text { the associations between ACEs, social support, } \\
\text { and negative emotional states (that is, anxiety, } \\
\text { depression, and stress) among incarcerated women. }\end{array}$ & 174 incarcerated women. & Cross-sectional study & $\begin{array}{l}\text { Medical Outcomes Study's Social Support and } \\
\text { Depression Anxiety Stress Scale (DASS-21) }\end{array}$ \\
\hline $\begin{array}{l}\text { Nancy Wolff et al. (2011) } \\
\text { USA [11] }\end{array}$ & $\begin{array}{l}\text { To examines the traumatic and stressful } \\
\text { event exposure history and psychiatric health } \\
\text { characteristics of soon-to-be released female } \\
\text { inmates who self-referred to specialty posttraumatic } \\
\text { stress disorder (PTSD) treatment. }\end{array}$ & 209 female inmates & $\begin{array}{l}\text { Structured diagnostic } \\
\text { clinical interviews. }\end{array}$ & $\begin{array}{l}\text { Clinician-Administrated PTSD Scale, } \\
\text { Structured Clinical Interview for DSM-IV Non- } \\
\text { patient Version (SCID-NP), Trauma History } \\
\text { Questionnaire, and The Life Stressor Checklist- } \\
\text { Revised (LSC-R) }\end{array}$ \\
\hline $\begin{array}{l}\text { Sygit-Kowalkowska et al. } \\
\text { (2017) Poland [12] }\end{array}$ & $\begin{array}{l}\text { To analyze how psychological resilience } \\
\text { differentiates mental states of incarcerated women } \\
\text { and to identify the predictor of mental well-being in } \\
\text { these groups. }\end{array}$ & 46 incarcerated women. & Descriptive correlational & $\begin{array}{l}\text { The Resilience Measurement Scale-RMS- } 25 \\
\text { and Hospital Anxiety and Depression Scale } \\
\text { (HADS-M) scale }\end{array}$ \\
\hline $\begin{array}{l}\text { Sanchez et al. (2021) } \\
\text { Spain [14] }\end{array}$ & $\begin{array}{l}\text { To examines the prevalence of suicide attempts } \\
\text { among incarcerated women. }\end{array}$ & 174 incarcerated women & Descriptive correlational & $\begin{array}{l}\text { Depression Anxiety Stress Scale (DASS-21), } \\
\text { Medical Outcomes Study Social Support Survey } \\
\text { (MOSS-SSS), and AUDIT-C }\end{array}$ \\
\hline $\begin{array}{l}\text { Scott et al. (2015) USA } \\
\text { [15] }\end{array}$ & $\begin{array}{l}\text { To examines patterns of trauma exposure and the } \\
\text { relationship between trauma exposure and mental } \\
\text { disorders. }\end{array}$ & 810 incarcerated women & Descriptive correlational & $\begin{array}{l}\text { Life stressor Checklist Revised, Global } \\
\text { Appraisal of Individual Needs (GAIN) }\end{array}$ \\
\hline $\begin{array}{l}\text { Bina et al. (2020) } \\
\text { Indonesia [16] }\end{array}$ & To determine the level of anxiety. & 128 women in prison & Critical study & $\begin{array}{l}\text { Spielberger's The State Anxiety Inventory } \\
\text { (STAI) }\end{array}$ \\
\hline
\end{tabular}

In addition, fear also arises as a result of discomfort in prison [9]. There was a relationship between anxiety, depression, and stress with social support variables $(p<0.01)$ [10]. PTSD in female prisoners before their release was reported by Wolff et al. [11] with various forms of trauma: Physical, sexual, and combination of both. Sygit-Kowalkowska et al. [12] in his research found that the minimum and maximum scores on depression were one and 18, anxiety zero and 16. Grief and loss were felt by prisoners [13]. Alcohol misuse was approximately twice as frequent among women reporting suicide attempts (55.6\% vs. $25.9 \%$, $\chi^{2}=9.50$, and $\mathrm{p}=0.002$ ), and drug consumption was 4 times higher among them when compared with those who have not attempted suicide $(55.6 \%$ vs. $13.6 \%$, $\chi^{2}=24.98$, and $\left.p<0.001\right)$ [14]. Female detainees average $6.1(S D=4.9)$ types of trauma in their lifetimes. In addition, women reporting suicide attempts had higher levels of depression ( $M=29.85$ vs. $M=12.57$ ), anxiety $(M=29.41$ vs. $M=12.86)$, and stress $(M=30.07$ vs. $M=15.48)$ [15]. Bina et al. [16] in her research found that the highest prisoner's anxiety level was in the moderate category as much as $44.5 \%$ and the lowest was in the panic category as much as $5.5 \%$.

\section{Female prisoner characteristic}

2652 female prisoners are respondents in this scoping review. Respondents are female prisoners who experience mental health problems in prison, respondents were between 18 and 80 years old, most are married and have children.

\section{Discussion}

This review aimed to identify the mental health problems of female prisoners in prison. Based on the analysis of nine articles, it was found that the mental health problems of female prisoners include anxiety, depression, substance abuse, stress, loss and grief, trauma, and suicide attempts that are at risk of psychological distress.

Anxiety reported by female prisoners [12], [16], it is influenced by the ability to adjust to a new place. This anxiety has an impact on psychological and emotional stress that cause violence in prison in the form of sexual and physical violence such as beatings, slapping, and being threatened with weapons. The

Table 2: Checklist mental health problems

\begin{tabular}{|c|c|c|c|c|c|c|c|c|}
\hline \multirow[t]{2}{*}{ Author, year } & \multicolumn{8}{|c|}{ Mental Health Problems } \\
\hline & Anxiety & Depression & Stress & Substance abuse & PTSD & Loss and grief & Suicide attempts & Fear \\
\hline Tyler et al. (2019) & $\sqrt{ }$ & $\sqrt{ }$ & $\mathrm{N} / \mathrm{A}$ & $\sqrt{ }$ & $\sqrt{ }$ & $\mathrm{N} / \mathrm{A}$ & $\sqrt{ }$ & $\mathrm{N} / \mathrm{A}$ \\
\hline Harner and Riley (2013) & N/A & N/A & N/A & $\mathrm{N} / \mathrm{A}$ & $\mathrm{N} / \mathrm{A}$ & $\mathrm{N} / \mathrm{A}$ & N/A & $\sqrt{ }$ \\
\hline Caravaca-Sanchez et al. (2019) & $\sqrt{ }$ & $\sqrt{ }$ & $\sqrt{ }$ & $\mathrm{N} / \mathrm{A}$ & $\mathrm{N} / \mathrm{A}$ & $\mathrm{N} / \mathrm{A}$ & $\mathrm{N} / \mathrm{A}$ & $N / A$ \\
\hline Nancy Wolff et al. (2011) & N/A & $\mathrm{N} / \mathrm{A}$ & N/A & $\mathrm{N} / \mathrm{A}$ & $\sqrt{ }$ & $\mathrm{N} / \mathrm{A}$ & $\mathrm{N} / \mathrm{A}$ & $N / A$ \\
\hline Sygit-kowalkowska (2017) & $\sqrt{ }$ & $\sqrt{ }$ & N/A & N/A & $\mathrm{N} / \mathrm{A}$ & $\mathrm{N} / \mathrm{A}$ & N/A & N/A \\
\hline Harner et al. (2011) & N/A & $\mathrm{N} / \mathrm{A}$ & N/A & $\mathrm{N} / \mathrm{A}$ & $\mathrm{N} / \mathrm{A}$ & $\sqrt{ }$ & $\mathrm{N} / \mathrm{A}$ & $N / A$ \\
\hline Caravaca-Sanchez et al. (2021) & $\sqrt{ }$ & $\sqrt{ }$ & $\sqrt{ }$ & $\sqrt{ }$ & $\mathrm{N} / \mathrm{A}$ & $\mathrm{N} / \mathrm{A}$ & $\sqrt{ }$ & $\mathrm{N} / \mathrm{A}$ \\
\hline Scott et al. (2015) & N/A & $\mathrm{N} / \mathrm{A}$ & N/A & $\mathrm{N} / \mathrm{A}$ & $\mathrm{N} / \mathrm{A}$ & $\mathrm{N} / \mathrm{A}$ & $\sqrt{ }$ & $\mathrm{N} / \mathrm{A}$ \\
\hline Bina et al. (2020) & $\sqrt{ }$ & $\mathrm{N} / \mathrm{A}$ & N/A & $\mathrm{N} / \mathrm{A}$ & $\mathrm{N} / \mathrm{A}$ & $\mathrm{N} / \mathrm{A}$ & $\mathrm{N} / \mathrm{A}$ & $N / A$ \\
\hline
\end{tabular}


anxiety of female prisoners arises because of negative emotions due to the problems they face, stressors, feelings of failure, feelings of insecurity [16], and length of detention [12]. Most of the respondents are married and have children; marital status is one of the stressors for female prisoners caused by limitations in maintaining family integrity, the role of mothers in raising children, and conflicts in marriage with husbands [17]. In addition, most prisoners who are currently in detention carry out their role as sole caregivers, causing stress because they think about their children in the future [18]. The conditions in prison play an important role in the anxiety of female prisoners because prisoners have to adapt to their new place and role. Women's prisons have mandatory rules and activities that must be followed so that female prisoners feel that their freedom is very limited. The prison environment has a deep and negative impact on the physical, mental, and emotional well-being of inmates [19], [20].

Moderate to severe anxiety will cause feelings of stress so that it will cause mental health problems associated with various physical and mental disorders. Moderate stress levels will result in normal adaptation to daily demands; however, excessive manifestations of psychological stress with physical and emotional reactions, and symptoms vary. Stress experienced in prison environments is strongly associated with anxiety and depression, and more often occurs among new prisoners, thus increasing the risk of suicide in prison [21].

Anxiety and depression caused by poor emotional support are negatively associated with readiness for care and treatment [22]. However, Harner and Riley [9] mentioned that several female prisoners stated that while in detention, their mental health tended to improve. In addition, depression can cause mood swings that affect physical and somatic conditions such as disturbed sleep patterns, fatigue, and decreased concentration [23]. As for the increase in death due to drug abuse, mental disorders, sexual violence, and the occurrence of complex chronic diseases such as hypertension, asthma, diabetes, heart disease, and sexually transmitted diseases [24]. The occurrence of depression can be influenced by internal and external factors. Internal factors include age, education level, marital status, and length of sentence, while external factors are the existing programs in prisons.

The traumatic experiences of some female prisoners made their mental health problems even more severe. Wolff et al. [11] said that more than $50 \%$ of female prisoners were exposed to traumatic events, they reported experiencing at least one incident of physical and sexual violence perpetrated by someone they knew, and this made them experience serious mental health problems. This is reinforced by Caravaca-Sanchez [10] which stated that $21.8 \%$ of female prisoners reported experiencing sexual violence in their childhood. In another article, trauma can be caused by the loss of a loved one [15]. The process of grieving and loss is often associated with the loss of a loved one, for some female prisoners, it is very difficult because they feel prison is not a place to grieve, so they bury their feelings of loss, so it adds to problems in their mental health [13].

Drug abuse is a serious problem for female inmates in prisons. Two articles mention that the prevalence of drug and alcohol use among female prisoners is the highest in mental health problems [8], [14].

Suicidal ideation is an early expression of vulnerability to self-injurious behavior [25]. The average suicide rate among female inmates is higher than male inmates [26]. However, Caravaca-Sanchez et al. [14] stated that of several mental health problems, suicide attempts were still lower than alcohol and drug abuse. In addition, when compared with studies on male prisoners, studies related to the prevalence of suicide among female prisoners and the factors that discuss suicidal behavior contribute to suicide much less [26].

\section{Conclusion}

This review highlights some of the mental health problems found in female prisoners: There are still very few studies related to mental health problems in female prisoners when compared to research conducted on male prisoners, from nine articles discussing mental health problems in prisoners, only one article used a qualitative approach, a qualitative approach is needed to further explore mental health problems for female prisoners and how to solve it. Articles are dominated by the USA and several European countries, only one article was from Asian represented by Indonesia. Based on the findings, it is suggested for further research to focus on how female prisoners can access mental health services in prisons to overcome their mental health problems, conduct a deeper exploration of the extent to which mental health services in prisons have been carried out so far.

\section{References}

1. Fazel S, Hayes AJ, Bartellas K, Clerici M, Trestman R. Menta health of prisoners: Prevalence, adverse outcomes, and interventions. Lancet Psychiatry. 2016;3(9):871-81. https://doi. org/10.1016/s2215-0366(16)30142-0 PMid:27426440

2. Yi Y, Turney K, Wildeman $\mathrm{C}$. Mental health among jail and prison inmates. Am J Mens Health. 2017;11(4):900-9. https:// 
doi.org/10.1177/1557988316681339

PMid:27932588

3. Reingle Gonzalez JM, Connell NM. Mental health of prisoners: Identifying barriers to mental health treatment and medication continuity. Am J Public Health. 2014;104(12):2328-33. https:// doi.org/10.2105/ajph.2014.302043

PMid:25322306

4. James DJ, Glaze LE. Mental Health Problems of Prison and Jail Inmates. Washington, DC: U.S. Department of Justice, Office of Justice Programs, Bureau of Justice Statistics; 2006. https:// doi.org/10.1037/e557002006-001

5. Wilper AP, Woolhandler S, Boyd JW, Lasser KE, McCormick D, Bor DH, et al. The health and health care of US prisoners: Results of a nationwide survey. Am J Public Health. 2009;99(4):666-72. https://doi.org/10.2105/ajph.2008.144279 PMid:19150898

6. Fedock GL. Women's psychological adjustment to prison: A review for future social work directions. Soc Work Res. 2017;41(1):31-42. https://doi.org/10.1093/swr/svw031

7. Arksey H, O'Malley L. Scoping studies: Towards a methodological framework. Int J Soc Res Methodol. 2005;8(1):19-32. https:// doi.org/10.1080/1364557032000119616

8. Tyler N, Miles HL, Karadag B, Rogers G. An updated picture of the mental health needs of male and female prisoners in the UK: Prevalence, comorbidity, and gender differences. Soc Psychiatry Psychiatr Epidemiol. 2019;54(9):1143-52. https://doi. org/10.1007/s00127-019-01690-1

\section{PMid:30903239}

9. Harner HM, Riley S. The impact of incarceration on women's mental health: Responses from women in a maximumsecurity prison. Qual Health Res. 2013;23(1):26-42. https://doi. org/10.1177/1049732312461452

PMid:23034774

10. Caravaca-Sánchez F, Fearn NE, Vidovic KR, Vaughn MG. Female prisoners in spain: Adverse childhood experiences, negative emotional states, and social support. Health Soc Work. 2019;44(3):157-66. https://doi.org/10.1093/hsw/hlz013 PMid:31353392

11. Wolff N, Christopher Frueh B, Shi J, Gerardi D, Fabrikant N, Schumann BE. Trauma exposure and mental health characteristics of incarcerated females self-referred to specialty PTSD treatment. Psychiatr Serv. 2011;62(8):954-8. https://doi. org/10.1176/ps.62.8.pss6208_0954

PMid:21807837

12. Sygit-Kowalkowska E, Szrajda J, Weber-Rajek M, Porażyński K, Ziółkowski M. Resilience as a predicator of mental health of incarcerated women. Psychiatr Pol. 2017;51(3):549-60. https:// doi.org/10.12740/pp/onlinefirst/62617 PMid:28866723

13. Harner HM, Hentz PM, Evangelista MC. Grief interrupted: The experience of loss among incarcerated women. Qual Health Res. 2011;21(4):454-64. https://doi.org/10.1177/1049732310373257 PMid:20581074

14. Caravaca-Sánchez F, Barry TJ, Aizpurua E, Ricarte JJ. Mental health, substance abuse, prison victimization and suicide attempts amongst incarcerated women. Eur $\mathrm{J}$ Criminol.
2021;2021:1-19. https://doi.org/10.1177/14773708211028471

15. Scott CK, Lurigio AJ, Dennis ML, Funk RR. Trauma and morbidities among female detainees in a large Urban Jail. Prison J. 2016;96(1):102-25. https://doi.org/10.1177/0032885515605490

16. Bina MY, Andriany M, Dewi NS. Anxiety in prisoners who are currently serving a prison term: A descriptive study in a class IIA women's prison in Semarang. Psychology. 2020;5(2):5. https:// doi.org/10.30604/jika.v5i2.294

17. Aini R. Pengaruh cognitive behavior therapy (CBT) terhadap penurunan derajat kecemasan pada narapidana yang akan bebas di Lembaga Pemasyarakatan Wanita klas II A Bandung. Scientica. 2015;2(1):58-71. https://doi.org/10.24198/ sosiohumaniora.v18i3.10121

18. Ferszt GG, Miller RJ, Hickey JE, Maull F, Crisp K. The impact of a mindfulness based program on perceived stress, anxiety, depression and sleep of incarcerated women. Int J Environ Res Public Health. 2015;12(9):11594-607. https://doi.org/10.3390/ ijerph120911594 PMid:26389932

19. Bradford A. An Examination of the Prison Environment: An Analysis of Inmate Concerns across Eight Environmental Dimensions. Tennessee: Electronic Theses and Dissertations; 2006.

20. Goomany A, Dickinson T. The influence of prison climate on the mental health of adult prisoners: A literature review. J Psychiatr Ment Health Nurs. 2015;22(6):413-22. https://doi.org/10.1111/ jpm.12231

PMid:26122924

21. Ahmad A, Mazlan NH. Stres dan Depresi: Studi perbandingan antara narapidana pria dan wanita di Semenanjung Malaysia. J Int IImu Hum IImu Sos. 2014;4(2):153-60. https://doi. org/10.26418/proyeksi.v24i2.2460

22. Narayan AJ, Kalstabakken AW, Labella MH, Nerenberg LS, Monn AR, Masten AS, et al. Intergenerational continuity of adverse childhood experiences in homeless families: Unpacking exposure to maltreatment versus family dysfunction. Am J Orthopsychiatry. 2017;87(1):3-14. https://doi.org/10.1037/ ort0000133

PMid:26752439

23. Cabeldue M, Blackburn A, Mullings JL. Mental health among incarcerated women: An examination of factors impacting depression and PTSD symptomology. Women Crim Just. 2019;29(1):52-72. https://doi.org/10.1080/08974454.2018.1433 099

24. Chen YS, Lai YL, Lin CY. The impact of prison adjustment among women offenders: A Taiwanese perspective. Prison J. 2014;94(1):7-29. https://doi.org/10.1177/0032885513512083

25. Palmer EJ, Connelly R. Depression, hopelessness and suicide ideation among vulnerable prisoners. Crim Behav Mental Health. 2005;15(3):164-70. https://doi.org/10.1002/cbm.4 PMid: 16575794

26. Favril L, O'Connor RC. Distinguishing prisoners who think about suicide from those who attempt suicide. Psychol Med. 2021;51(2):228-35. https://doi.org/10.31234/osf.io/83sdx PMid:31736457 